in combination, on emotional judgments. Perceptual \& Motor Skills, $54,635-641$.

Simon, C. R., \& WoHLwill, J. F. (1968). The role of expectation and variation in music. The Journal of Research in Music Education, 16, 227-238.
WeHNeR, W. L. (1966). The relation between six paintings by Paul Klee and selected musical compositions. The Journal of Research in Music Education, 15, 220-224.

(Manuscript received for publication June 30, 1986.)

\title{
NOTICE
}

\section{Abstracts of All Psychonomic Society Journal Articles Published in the Bulletin of the Psychonomic Society}

With the March 1987 issue, the Bulletin of the Psychonomic Society will launch the publication of a section that will contain abstracts of all articles that have appeared in recent issues of the other five Psychonomic Society journals-Animal Learning \& Behavior; Behavior Research Methods, Instruments, \& Computers; Memory \& Cognition; Perception \& Psychophysics; and Psychobiology. It is hoped that this feature will provide readers with additional access to information that will be of use in their work. 